\title{
PILATES PRATIMŲ POVEIKIS SĖDIMĄ DARBĄ DIRBANČIŲ ŽMONIŲ APATINESS NUGAROS DALIES FUNKCINEI BÜKLEI IR SKAUSMUI
}

\author{
Rima Margevičiūtè $\dot{e}^{1}$, Sigutė Norkiené $\dot{~}^{1,2}$ \\ ${ }^{1}$ Klaipèdos universiteto Sveikatos mokslu fakultetas, ${ }^{1,2} V$ Ṣ̌ Klaipédos jūrininku ligoninè
}

Raktažodžiai: pilateso (vok. pilates) metodo pratimai, apatinès nugaros dalies skausmas, sėdimas darbas.

\begin{abstract}
Santrauka
Šiuolaikinis gyvenimo tempas, sumažejęs fizinis aktyvumas, sėdimas darbas, netaisyklinga laikysena ir pan. turi itakos nugaros skausmams atsirasti. Dideli poveiki skausmo mažinimui, jo profilaktikai ir prevencijai turi taisyklingos padetys ir judesiai bei fiziniai pratimai. Priklausomai nuo apatinès nugaros dalies skausmo intensyvumo, jo kilmès, pacientui gali būti skiriami ịvairūs fiziniai pratimai. Pilateso treniruočių metodas - viena iš fizinių pratimų sistemų, populiarejjanti tiek sveikatingumo, tiek reabilitacijos srityse, gydant apatinés nugaros dalies skausmus.

Tyrimo tikslas buvo įvertinti pilateso pratimu poveiki sėdimą darbą dirbančių žmonių apatinės nugaros dalies funkcinei būklei ir skausmui. Tyrime dalyvavo 37 sẻdimą darbą dirbantys žmonès, jaučiantys lètinius apatinès nugaros dalies skausmus, ateję ì pirmają pilateso treniruotę. Taikyti anketinès apklausos, testavimo ir statistinès duomenų analizès metodai. Naudoti instrumentai: klausimynas, vizualinè analoginè skausmo skalè (VAS) ir liemens raumenų statinès ištvermès testai pagal McGill (2007). Atlikus tyrimą, rezultatai parode, kad po pilateso programos taikymo tiriamųjų statinès liemens raumenų ištvermès rodikliai statistiškai reikšmingai pagerejo. Apatinès nugaros dalies skausmo intensyvumas statistiškai reikšmingai sumažejjo nuo vidutinio iki silpnai jaučiamo. Skausmą mažino didejjanti statinès liemens raumenų ištvermès pusiausvyra.
\end{abstract}

\section{Ivadas}

Apatinès nugaros dalies skausmas tampa viena labiausiai paplitusių ligų tiek Lietuvoje, tiek visame pasaulyje: šiuo negalavimu bent kartą gyvenime skundžiasi $60-90$ proc. išsivysčiusių šalių gyventojų [1]. Stuburo negalavimai, nurodant nedarbingumo priežastis, yra antroje vietoje po peršalimų [2]. Išorinių faktorių įtaką nugaros skausmui atsirasti reikšmingai sustiprina eilè individualių žmogaus fiziologinių ir psichologinių charakteristikų: genetiniai veiksniai, patologiniai procesai, ilgai trunkanti netaisyklinga ir per didele stuburo struktūrų apkrova, psichologinè būklè. Dirbant sẻdimą darbą, nekeičiant kūno pozos, esant neergonomiškai darbo aplinkai, gali išsivystyti liemens raumenų jègos bei ištvermès pusiausvyros sutrikimai, vystosi degeneraciniai stuburo pakitimai. Nemažai autoriu (3-5) teigia, kad nepakankama liemens raumenu jèga ir ištvermé, ir ypač statinès liemens raumenų pusiausvyros sutrikimai - svarbūs veiksniai apatinès nugaros dalies skausmo atsiradimui. Apatinès nugaros dalies skausmas tampa didele sveikatos, socialine ir ekonomine problema. Praktinè medicina šiandien turi daug gydymo priemonių, tačiau statistiniai ir epidemiologiniai duomenys rodo, jog nugaros skausmų problemos aktualumas nemažèja, ji vis dar atrodo iki galo neišspręsta.

Teigiama, jog didžiausią poveikị skausmo mažinimui, jo profilaktikai ir prevencijai turi taisyklingos padetys ir judesiai bei fiziniai pratimai [6]. Priklausomai nuo apatinès nugaros dalies skausmo intensyvumo, jo kilmès, pacientui gali būti skiriami ịvairūs fiziniai pratimai. Pilateso metodas - viena iš fizinių pratimų sistemų, populiarejanti tiek sveikatingumo, tiek reabilitacijos srityse, gydant apatinès nugaros dalies skausmus [7].

Tyrimo objektas - pilateso pratimų poveikis sédimą darbą dirbančiu žmonių apatinès nugaros dalies funkcinei būklei ir skausmui.

Tyrimo tikslas - ịvertinti pilateso pratimų poveikị sèdimą darbą dirbančių žmonių apatinès nugaros dalies funkcinei būklei ir skausmui.

\section{Tyrimo metodika}

Tyrimo imtis sudaryta naudojantis netikimybiniu atrankos metodu, tiksline tiriamujų atranka. Pasirinkti tokie tyrimo imties sudarymo kriterijai - (1) jaučiamas nociceptinès kilmès skausmas apatinèje nugaros dalyje; (2) darbas sėdint ne mažiau kaip 5 valandas per dieną; (3) papildomo darbo, kuris gali paveikti apatinès nugaros 


\section{2}

dalies skausmo atsiradimą ar paūmèjimą, neturèjimas.

Tyrime dalyvavo 50 tiriamujų, atejjusių i pirmają savo pilateso treniruotę dviejuose sporto ir sveikatingumo klubuose, savanoriškai sutikusių bei pasirašiusių sutikimo formą. Nustatytas tyrimo sąlygas - atrankos kriterijus, lankymąsi pilateso užsièmimuose tris kartus per savaitę vieną mẻnesị (iš viso 12 kartų) - išpilde 37 tiriamieji.

Siekiant îvertinti pilateso pratimų poveikị sédimą darbą dirbančiu žmonių statinei liemens raumenų ištvermei, buvo taikyti anketinès apklausos, testavimo bei statistinès tyrimo duomenų analizès metodai.

Tyrimas atliktas $2014 \mathrm{~m}$. gruodžio - $2015 \mathrm{~m}$. kovo mènesiais. Sporto ir sveikatingumo klubų lankytojai buvo paprašyti užpildyti klausimynus. Atitikę kriterijus bei savanoriškai sutikę dalyvauti tyrime žmonès buvo paprašyti ịvertinti apatinès nugaros dalies skausmo intensyvumą per praejusią savaitę, panaudojant vizualinę analoginę skausmo skalę; t.p. testuojami liemens raumenų statinès ištvermès pajègumui išsiaiškinti.

Po mėnesị trukusių užsièmimų, be liemens raumenų

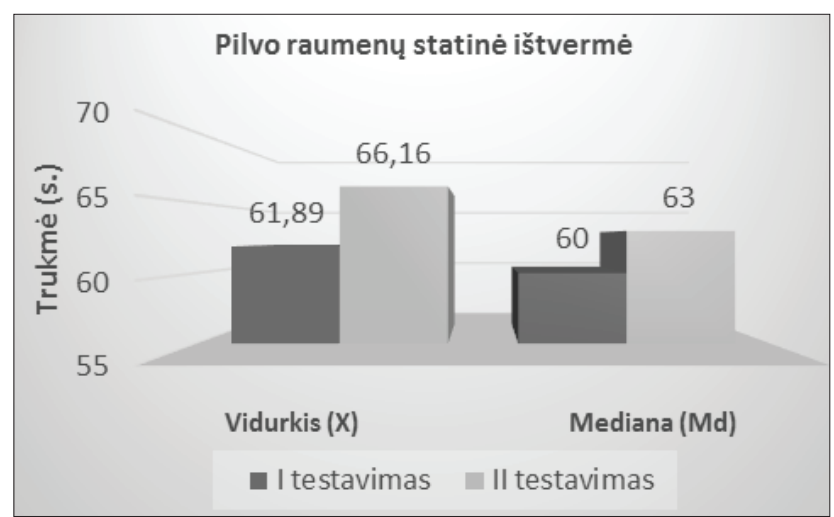

1 pav. Tiriamujų pilvo raumenų statinès ištvermès pokytis prieš ir po pilateso programos taikymo

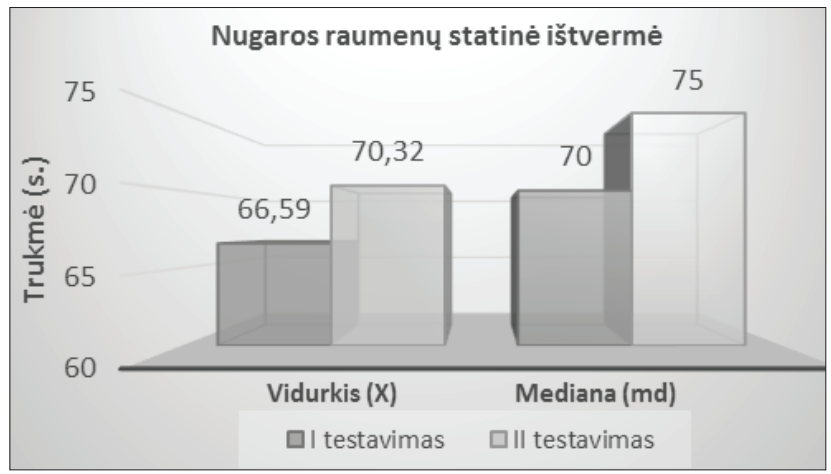

2 pav. Tiriamujų nugaros raumenų statinès ištvermès pokytis prieš ir po pilateso programos taikymo statinės ištvermės testavimo, dar kartą buvo tiriamas ir apatinès nugaros dalies skausmo intensyvumas, panaudojant VAS.

\section{Tyrimo rezultatai}

Liemens raumenu statinès ištvermès ivertinimas. Tiriamiesiems buvo įvertinta liemens raumenų statinè ištvermé prieš pradedant pilateso užsièmimus (I testavimas) ir po ménesio trukmès užsièmimų (II testavimas).

Tiriamujų pilvo raumenų statinès ištvermès vidurkis prieš tyrimą buvo $61,89 \mathrm{~s}, \mathrm{SD}-24,88$ (rodikliai svyravo intervale nuo $20 \mathrm{~s}$ iki $114 \mathrm{~s}$ ). Pakartotinai iqvertinus po dvylikos pilateso užsièmimų, stebimas pilvo raumenų statinès ištvermès pagerèjimas, kurio vidurkis padidèjo iki $66,16 \mathrm{~s}$, $\mathrm{SD}-24,10$ (rodikliai svyravo intervale nuo $27 \mathrm{~s}$ iki $115 \mathrm{~s}$ ). Pilvo raumenų statinès ištvermès vidurkis po pilateso programos pagerejjo statistiškai reikšmingai, 4,27 s (r=0,998; $\mathrm{p}=0,000$.) Pilvo raumenų statinès ištvermès rodikliai pagerejo visiems 37 tiriamiesiems (100\%). Imties rodiklių mediana (Md) prieš užsièmimus - $60 \mathrm{~s}$, po vieno mènesio trukmès užsièmimų - $63 \mathrm{~s}$ (1 pav.).

Tiriamosios grupés nugaros raumenų statinès ištver-

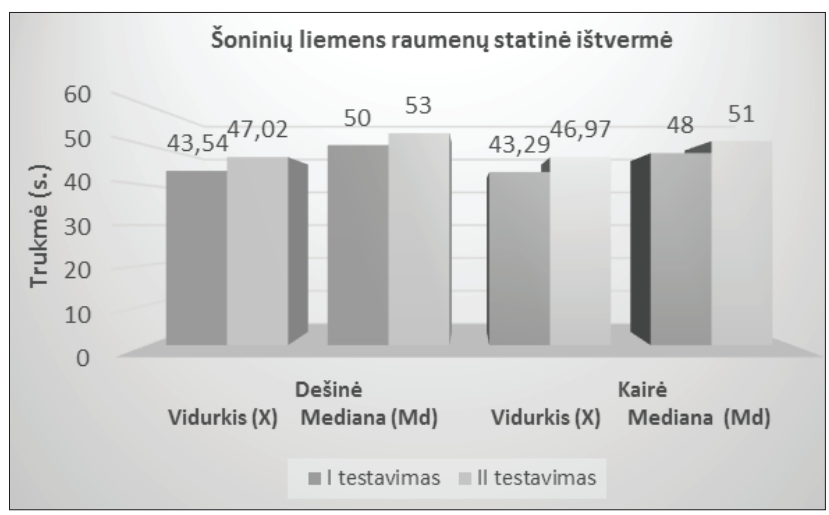

3 pav. Šoninių liemens raumenų statinès ištvermès pokytis prieš ir po pilateso programos taikymo

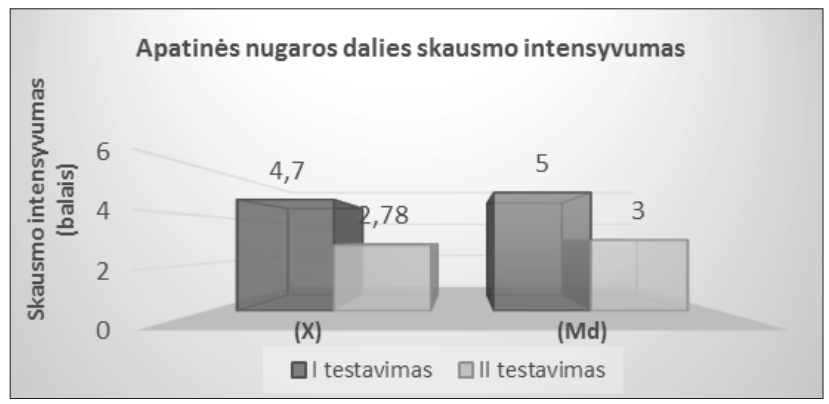

4 pav. Apatinès nugaros dalies skausmo intensyvumo pokytis prieš ir po pilateso programos taikymo 
mès vidurkis prieš pradedant užsièmimus buvo $66,59 \mathrm{~s}$, SD - 24,70 (rodikliai svyravo intervale nuo 20 s iki 100 s). Ivertinus tiriamujų nugaros raumenų statinès raumenų ištvermès rezultatus po dvylikos pilateso užsièmimų, galima teigti, jog vidutiniškai padèties išlaikymo laikas padidejjo statistiškai reikšmingai, $3,73 \mathrm{~s}(\mathrm{r}=0,095 ; \mathrm{p}=0,000)$ iki 70,32 s, SD - 24,38 (rodikliai svyravo intervale nuo25 $\mathrm{s}$ iki $110 \mathrm{~s}$ ). Nugaros raumenų statinès ištvermès rodikliai pagerejo 36 tiriamiesiems $(97,29 \%)$. Vienas tiriamasis parodè tą patị rezultatą prieš ir po programos. Imties rodiklių mediana $(\mathrm{Md})$ prieš užsièmimus - $70 \mathrm{~s}$, po mènesio trukmès užsièmimų $75 \mathrm{~s}$ ( 2 pav.).

Tiriamųų dešinės pusės šoninių liemens raumenų statinés ištvermès vidurkio rezultatas prieš pradedant užsièmimus buvo 43,54 s (rodikliai svyravo intervale nuo $10 \mathrm{~s}$ iki $85 \mathrm{~s}$ ), SD - 17,29.Po dvylikos pilateso užsièmimų vidurkis padidejo iki 47,02 s (rodikliai svyravo intervale nuo 15 iki 87 s), SD - 17,63. Dešinès pusès šoninių liemens raumenų statinès ištvermès vidurkis padidèjo 3,48 s (duomenys statistiškai patikimi: $r=0,996 ; p=0,000)$. Dešinès pusès liemens raumenų statinès ištvermès rodikliai pagerèjo 35 tiriamiesiems $(94,59 \%)$. Du tiriamieji parodè tą pati rezultatą tiek prieš, tiek po programos. Imties rodiklių mediana $(\mathrm{Md})$ prieš užsiėmimus - $50 \mathrm{~s}$, po vieno mènesio trukmès užsièmimų - $53 \mathrm{~s}$.

Ivertinus tiriamųu kairès pusès šoninių liemens raumenų ištvermę, vidurkis prieš pilateso programos taikymą buvo lygus 43,29 s (rodikliai svyravo intervale nuo $10 \mathrm{~s}$ iki 70 s), SD - 17,65. Ivertinus po dvylikos pilateso užsièmimų, stebimas kairès pusès liemens raumenų ištvermès pagerejimas, vidurkis padidejo iki 46,97 s (rodikliai svyravo intervale nuo $15 \mathrm{~s}$ iki $75 \mathrm{~s}$ ), SD - 17,84. Kairès pusès šoninių liemens raumenų statinès ištvermès vidurkis padidejo statistiškai reikšmingai, 3,68 s ( $r=0,991 ; p=0,000)$. Kairès pusès liemens raumenų statinès ištvermès rodikliai pagerejo visiems 37 tiriamiesiems (100\%). Imties rodikliu mediana $(\mathrm{Md})$ prieš užsièmimus $-48 \mathrm{~s}$, po vieno mėnesio trukmès užsièmimų - $51 \mathrm{~s}$ (3 pav.).

Tiriamuju apatinés nugaros dalies skausmo intensyvumo ivvertinimas. Skausmo intensyvumas buvo vertinamas pagal vizualinę analoginę skalę (VAS). Prieš pradedant pilateso užsièmimus tiriamųjų apatinès nugaros dalies skausmo intensyvumo vidurkis buvo 4,7 balai, SD - 1,24, tiriamieji jaute vidutinio intensyvumo skausmus (rodikliai svyravo intervale nuo 3 iki 8 balų). Skausmo intensyvumo rodiklių mediana $(\mathrm{Md})$ prieš užsièmimus -5 balai. Po mėnesio trukmès pilateso užsiėmimų tiriamųų apatinès nugaros dalies skausmo intensyvumo vidurkis sumažèjo 1,92 balais iki 2,78 balų, SD - 0,79, jaučiamo skausmo intensyvumas apibūdinamas kaip silpnas (rodikliai svyravo intervale nuo 1 iki 5 balų). Skausmo intensyvumo rodiklių mediana (Md) po mėnesio laiko trukmès užsièmimų - 3 balai. Jaučiamo skausmo intensyvumas sumažejo visiems 37 tiriamiesiems (100\%). Skausmo intensyvumas sumažèjo statistiškai reikšmingai (duomenys statistiškai patikimi: $\mathrm{r}=0,839 ; \mathrm{p}=0,000)(4 \mathrm{pav}$.$) .$

Sasaju tarp skausmo intensyvumo ir statinès liemens raumenu pusiausvyros ivertinimas. Atlikus statinès pilvo, nugaros ir šoninių liemens raumenų ištvermès testus, nustatyti santykiai tarp pilvo ir nugaros raumenų ištvermès, tarp dešinès ir kairès pusès raumenų ištvermès, tarp dešinès ir kairès pusės šoninių raumenų ir nugaros raumenų ištvermès.

Prieš pradedant pilateso užsièmimus tiriamųjų pilvo ir nugaros raumenų ištvermès santykio vidurkis buvo 0,96 , tačiau rodikliai pasiskirste labai netolygiai- nuo 0,66 iki 3,08 ; SD - 0,39. İvertinus tuos pačius rodiklius po mènesio trukmès užsièmimų, santykio vidurkis beveik nepakito, buvo 0,$96 ; \mathrm{SD}-0,27$. Atlikta statistinè analizè nenustatè statistiškai reikšmingo pilvo ir nugaros raumenų ištvermès santykio pokyčio, tačiau daugumos tiriamujų rezultatai arteja prie siekiamo santykio rodiklio - 1, todèl pratęsus pilateso programos taikymą arba didinant imtị, tikètina, kad galima būtų fiksuoti statistiškai reikšmingus pokyčio rezultatus.

İvertinus tiriamujų dešinès ir kairès pusių liemens raumenų statinès ištvermès santyki prieš pradedant užsièmimus, nustatytas vidurkis - 1,05 , SD - 0,36. Žemiausias nustatytas santykis - 0,77, aukščiausias - 3. Po 12 užsièmimų santykių vidurkis sumažèjo iki 1,02, SD - 0,19. Atlikta statistinè analizè nenustate statistiškai reikšmingo dešinès ir kairès pusès liemens raumenų statinès ištvermès santykio pokyčio, tačiau stebima rodiklių gerèjimo tendencija.

Tyrimo pradžioje tiriamujų dešinès liemens pusès statinès ištvermès santykis su nugaros raumenų statine ištverme buvo $0,68, \mathrm{SD}-0,24 ; \mathrm{II}$ testavimo metu - 0,72, SD - 0,22. Kairès liemens pusès statinès raumenų ištvermès santykis su nugaros raumenų statine ištverme tyrimo pradžioje buvo $0,66, \mathrm{SD}-0,22$; II testavimo metu -0,68, SD - 0,18. Šoninių liemens raumenų statinès ištvermès santykis su nugaros raumenų statine ištverme turi būti ne didesnis už 0,75 . Atlikta statistinè analizè nenustate statistiškai reikšmingo šoniniu liemens raumenu statinès ištvermès ir nugaros raumenų statinès ištvermès santykio pokyčio, tačiau daugumos tiriamujų rezultatai arteja prie siekiamo santykio rodiklio $-0,75$. Pratęsus pilateso programos taikymą arba didinant imtị, tikètina, kad galima būtų fiksuoti statistiškai reikšmingus pokyčio rezultatus.

Nustačius santykius tarp atskirų liemens raumenų grupių statinès ištvermès, ịvertintos sąsajos tarp skausmo intensyvumo ir statinès liemens raumenų ištvermès pusiausvyros. Statistine apatinès nugaros dalies skausmo intensyvumo ir statinės pilvo ir nugaros raumenų ištvermés 


\section{4}

pusiausvyros I ir II testavimo duomenų analizė patvirtina statistiškai reikšmingą neigiamą koreliaciją tarp jų ( $\mathrm{r}=-$ $0,755, \mathrm{p}=0,048$, kai $\mathrm{p}<0,05)$.

Statistinè apatinès nugaros dalies skausmo intensyvumo ir statinès dešinès ir kairès pusių liemens raumenu ištvermès pusiausvyros I ir II testavimo duomenu analizė rodo egzistuojant nežymų neigiamą ryšị tarp šių kintamųu $(\mathrm{r}=-0,209, \mathrm{p}=0,039$, kai $\mathrm{p}<0,05)$.

Statistinè apatinès nugaros dalies skausmo intensyvumo ir dešinès pusès liemens raumenų statinès ištvermès santykio su nugaros raumenų statine ištverme I ir II testavimo duomenų analizė rodo statistiškai reikšmingą ryši tarp kintamujuc $(r=-0,405, p=0,026$, kai $\mathrm{p}<0,05)$.

Statistinè apatinès nugaros dalies skausmo intensyvumo ir kairès pusès liemens raumenų statinès ištvermès santykio su nugaros raumenų statine ištverme I ir II testavimo duomenų analizė rodo statistiškai reikšmingą ryši tarp kintamujų ( $(\mathrm{r}=-0,372, \mathrm{p}=0,043$, kai $\mathrm{p}<0,05)$.

Gauti rezultatai pavirtina, kad didèjant priešingų liemens raumenu grupių pusiausvyrai, apatinès nugaros dalies skausmas mažèja.

\section{Rezultatų aptarimas}

Po mènesi laiko trukusių pilateso užsièmimų, tyrimo dalyvių apatinès nugaros dalies skausmo intensyvumas sumažejo nuo vidutinio intensyvumo iki silpno. Skausmo intensyvumas po pilateso užsièmimų sumažèjo statistiškai reikšmingai. Nors skausmą kiekvienas žmogus vertina subjektyviai, tačiau jo sumažejjimas yra vienas iš požymių, jog programa yra efektyvi. Nemažai mokslininkų tyre pilateso pratimų programos poveikị lètiniam nespecifiniam apatinès nugaros dalies skausmo intensyvumui [8-11], tačiau vèliausi sisteminių apžvalgų duomenys rodo, jog gaunami šių tyrimų rezultatai yra labai nepastovūs [12-14].Tai gali būti todèl, kad atlikti tyrimai skirtingomis imtimis, ilgesniu ar trumpesniu intervencijos periodu, naudojantis nevalidžiais ar skirtingais tyrimo instrumentais ar tiksliai neapibūdinant intervencijos. Šio tyrimo metu pasiekto skausmo intensyvumo sumažejimo vidurkis 1,92 balais pagal VAS yra labai panašus ị vieno naujausių Natour ir kt. (2015) mokslininkų atlikto tyrimo rezultatus [15]. Jų tyrimo duomenys rodo, jog tiriamujų skausmo intensyvumas vidutiniškai sumažèjo 1,59 balais. Autoriai, ịvertinę gautus tyrimo rezultatus, teigia, jog pilateso metodas yra efektyvi ir saugi reabilitacijos priemoné, sumažinanti pacientų jaučiamą apatinès nugaros dalies skausmą. V. Gladwell ir kt. atliko tyrimą taip pat siekdami ịvertinti apatinès nugaros dalies skausmo intensyvumo pokyčius taikant keturių savaičių pilateso pratimų programą [16], tačiau jų gauti skausmo intensyvumo pokyčio rodikliai buvo mažesni, t.y. šiame darbe pristatomo tyrimo skausmo sumažejjimas buvo didesnis.
Tyrimais nustatyta, kad besiskundžiančių apatinès nugaros dalies skausmais žmonių liemens raumenų ištvermé yra mažesnè, lyginant su sveikujų [17]. Ją didinti galima atliekant pilateso pratimus [18-19]. Šiame darbe pristatomo tyrimo rezultatai sutampa su minètu autorių tyrimų rezultatais - po 12 pilateso užsièmimų tiriamujų statinè liemens (pilvo, nugaros, dešinès, kairès pusių) raumenų ištvermé padidejo.

Ivertinus sąsajas tarp jaučiamo skausmo intensyvumo ir statinès liemens raumenų pusiausvyros prieš ir po pilateso programos, tiriamujų jaučiamo skausmo intensyvumas po užsièmimų sumažèjo, mažèjant liemens raumenų statinès ištvermès asimetrijai. Pilvo-nugaros ir liemens šoninių raumenų (kairès - dešinès pusių) statinès ištvermès santykiai artėjo link vieneto, kairès ir dešinès pusių liemens raumenų santykis su nugaros raumenų statine ištverme neviršijo 0,75 . Tai rodo didejjantị liemens stabilumą. S. McGill teigia, jog pilvo-nugaros ir kairès-dešinès liemens raumenu statinè ištvermè turi būti simetriška [3]. Asimetrija gali būti viena iš nugaros skausmo priežasčių. Skausmo sumažèjimą galimai lëmè ir pagerejusi propriorecepcija, dalyviai pradejo labiau kontroliuoti savo laikyseną. Chae-Woo Lee, Ju Hyun, Seong Gil Kim (2014) savo atliktame tyrime nustate, jog taikant pilateso pratimų ant kilimèlio programą sèdimą darbą dirbantiems ir jaučiantiems lètinị nugaros skausmą žmonèms, ženkliai sumažèja jaučiamo skausmo intensyvumas, sustiprèja liemenị stabilizuojantys raumenys, pagereja pusiausvyros kontrolè bei laikysena [20].

\section{Išvados}

1. Po mėnesị laiko trukusių pilateso užsièmimų, tiriamujų statinès liemens (pilvo, nugaros, dešinès ir kairès pusių) raumenų ištvermès rodikliai statistiškai reikšmingai pagerejo $(p<0,01)$.

Ivertinus santykius tarp pilvo ir nugaros raumenų ištvermès, tarp dešinès ir kairès pusès liemens raumenų ištvermès, tarp dešinès ir kairès pusès šoninių liemens raumenų ir nugaros raumenų ištvermès, nustatyta, jog rodikliai prieš ir po mėnesị trukusių pilateso užsièmimų statistiškai reikšmingai nesiskyrè, tačiau stebima rodikliu gerẻjimo tendencija, pilvo - nugaros, kairès - dešinès pusių liemens raumenų ištvermès asimetrija mažèjo, santykiai artėjo link 1, dešinès pusès- nugaros bei kairès pusès - nugaros raumenų ištvermès santykiai neviršijo 0,75 .

2. Po ménesị laiko trukusių pilateso užsièmimų tiriamuju apatinès nugaros dalies skausmo intensyvumas statistiškai reikšmingai sumažèjo nuo vidutinio iki silpnai jaučiamo $(\mathrm{p}<0,01)$.

3. Apatinès nugaros dalies skausmą mažino didèjanti statinès liemens raumenų ištvermés pusiausvyra. 


\section{Literatūra}

1. Ščiupokas A. Skausmo diagnostika ir sindromologija. Kaunas, AB Spauda, 2012.

2. Mafuyai MY, Babangida BG, Mador ES, Bakwa DD, Jabil YY. The increasing cases of lower back pain in developed nations: a reciprocal effect of development. Academic Journal of Interdisciplinary Studies 2014; 3(5).

3. McGill S. Low back disorders: evidence - based prevention and rehabilitation. 2nd edition. Human Kinetics: Northeastern University 2007.

4. Neumann DA. Kinesiology of the musculosceletan system. USA, Philadelphia: Mosby 2002.

5. Dudonienè V. Stuburo stabilizavimo pratimai. Studijų knyga. Kaunas, LKKA, 2008.

6. Bigos SJ, Holland J, Holland C, Webster JS, Battie M, Malmgren JA. High-quality controlled trials on preventing episodes of back problems: Systematic literature review in working-age adults 2009; 9:147-168.

7. Di Lorenzo CE. Pilates, what is it? Should it be used in rehabilitation? Sports Health 2011; 3(4):352-361. http://dx.doi.org/10.1177/1941738111410285

8. Gagnon L. Efficacy of Pilates exercises as therapeutic intervention in treating patients with low back pain. $\mathrm{PhD}$ thesis. Knoxville: University of Tennessee 2005.

9. Marshall PW, Kennedy S, Brooks C, Lonsdale C. Pilates exercise or stationary cycling for chronic nonspecific low back pain: does it matter? A randomized controlled trial with 6-month follow-up 2013; 38:952-959.

10. Miyamoto GC, Costa LO, Galvanin T, Cabral CM. The efficacy of the addition of the Pilates method over a minimal intervention in the treatment of chronic nonspecific low back pain: a study of a randomized controlled trial. Physical Therapy 2013; 93(3):310.

http://dx.doi.org/10.2522/ptj.20120190

11. Wajswelner H, Metcalf B, Bennell K. Clinical Pilates versus general exercise for chronic low back pain: randomized trial. Medicine and Science in Sports and Exercise 2012; 44:11971205 .

http://dx.doi.org/10.1249/MSS.0b013e318248f665

12. Pereira LM, Obara K. Dias J.M. Comparing the Pilates method with no exercise or lumbar stabilization for pain and functionality in patients with chronic low back pain: Systematic review and meta-analysis. Clinical Rehabilitation 2012; 26: 10-20. http://dx.doi.org/10.1177/0269215511411113

13. Posadzki P, Lizis P, Hagner-Derengowska M. Pilates for low back pain: A systematic review. Complementary Therapies in Clinical Practice 2011; 17:85-89. http://dx.doi.org/10.1016/j.ctcp.2010.09.005

14. Wells C, Kolt GS, Mashall P, Hill B, Bialocerkowski A. Effectives of Pilates exercise in treating people with chronic low back pain: a systematic review of systematic reviews. BMC Medical Research Methodology 2013; 19:13-17.

15. Natour J., De Araujo Cazotti L., Ribeiro L.H., Baptista A.S., Jones A. Pilates improves pain, function and quality of life in patients with chronic low back pain: a randomized controlled trial. Clinical Rehabilitation, 2015; 29(1):59-68.

http://dx.doi.org/10.1177/0269215514538981
16. Gladwell V, Head S, Haggar M, Beneke R. Does a program of Pilates improve chronic non-specific low back pain? Journal of Sport Rehabilitation 2006; 15:338-350.

17. Bala K, Gakhar M, Jagga V. Effect of Endurance Training Of Trunk Extensor Muscles on Pain and Endurance in Patients with Sub Acute Nonspecific Low Backache. Journal of Exercise Science and Physiotherapy 2012; 8(2):82-86.

18. Sekendiz B, Altun O, Korkusuz F, Akin S. Effects of Pilates exercise on trunk strength, endurance and flexibility in sedentary adult females. Journal of Bodywork and Movement Therapies 2007; 11(4):318-326. http://dx.doi.org/10.1016/j.jbmt.2006.12.002

19. Rogers K, Gibson A. Eight-week traditional mat Pilates training program effects on adult fitness characteristics. Research Quarterly for Exercise and Sport 2009; 80(3):569-574. http://dx.doi.org/10.1080/02701367.2009.10599595

20. Lee ChW, Hyun J, Kim SG. Influence of Pilates mat and apparatus exercises on pain and balance of business women with chronic low back pain. Journal of Physical Therapy Science 2014; 26(4):475-477.

http://dx.doi.org/10.1589/jpts.26.475

\section{THE IMPACT OF PILATES EXERCISES ON FUNCTIONAL STATE AND PAIN OF LOW BACK FOR PEOPLE WHO PERFORM SEDENTARY WORK \\ R. Margevičiūtė, S. Norkienè}

Key words: Pilates exercises, low back pain, sedentary work. Summary

A modern pace of life, decreased physical activity, sedentary work, poor posture and so on influence the emergence of back pain. Correct positions, movements and physical exercises have significant impact on the reduction of pain, prophylaxis and prevention. A variety of physical exercises may be assigned to a patient, depending on the low back pain intensity and its origin. Pilates method is one of exercises systems, which become more and more popular in low back pain treatment both in fitness and rehabilitation fields.

The aim of the study was to evaluate the impact of Pilates exercises on functional state and pain of low back for people who perform sedentary work. In this study participated 37 sedentary work employees, who have felt chronic low back pain. All participants came to their first Pilates practice. The study utilized quantitative method of data collection. The instruments used in the study: questionnaire, visual analogue pain scale (VAS), static trunk muscular endurance tests by S. McGill (2007).

After practicing Pilates for a month, static endurance of trunk muscle increased statistically significantly. Low back pain intensity has decreased statistically significantly from average to weak. Low back pain has been reduced by the increased balance of static endurance among the torso muscle groups.

Correspondence to: amirlt@yahoo.com

Gauta 2015-11-11 